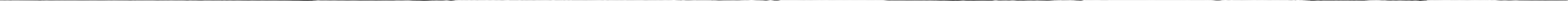




\section{Marta Rodríguez, descolonizando la representación documental latinoamericana}

\section{Artículo de reflexión}

Recibido: 2 de febrero de 2017

Aprobado: 10 de abril de 2017

Mtra. Marta Rodríguez de Silva

Fundación Cine Documental

cinemestizo@gmail.com

PhD. Pedro Pablo Gómez

Universidad Distrital Francisco José de Caldas

ppgomezm@udistrital.edu.co

Cómo citar este artículo: Gómez, Pedro Pablo (2017). Marta Rodríguez, descolonizando la representación documental latinoamericana. Estudios Artísticos: revista de investigación creadora, 3 (3) pp. 119-135. DOI: https://doi.org/10.1448/ear. v3i3.12532

Chircales (1964-1971). Fotografía de Jorge Silva.

\section{Resumen}

En esta conversación entre la cineasta documental Marta Rodríguez y Pedro Pablo Gómez, antes que hacer un recorrido cronológico por el trabajo la artista, se abordan problemas tranversales que están presentes a lo largo de su obra: el cine documental como modo de representación; la construcción de una metodología del cine documental latinoamericano; el carácter decolonial de la obra de Rodríguez y su compromiso indeclinable durante más de cuatro décadas de acompañar las luchas de campesinos, indígenas y afrodescendientes, entre otros. Y es en este abordaje donde Marta Rodríguez, haciendo uso de una memoria extraordinaria, puede tejer un relato en el que se destaca la ética de la artista y su compromiso indeclinable de denuncia de las injusticias sociales, utilizando las tecnologías del cine, no para hablar por las víctimas, sino para hacer escuchar sus voces y mantener vivas sus imágenes; unas imágenes que interpelan el discurso colonial mediante el cual se ha tejido nuestro relato de nación.

\section{Palabras clave}

Marta Rodríguez, Cine documental latinoamericano, metodología del documental, descolonización de la imagen, historia del cine documental.

\section{Marta Rodríguez, Decolonizing Latin American Film Representation}

In this conversation between the documentary filmmaker Marta Rodríguez and Pedro Pablo Gómez, before embarking on a chronological tour of the artist's work, we deal with the transverse problems that are present throughout her work: documentary cinema as a mode of representation; the construction of a Latin American documentary film 
methodology; the decolonial nature of Rodríguez's work and her constant commitment for more than four decades to accompany the struggles of peasants, indigenous and Afro-descendants, among others. It is with this approach that Marta Rodríguez, making use of an extraordinary memory, can weave a story that highlights the ethics of the artist and her indeclinable commitment to denounce social injustices, using the technologies of cinema not to speak instead of the victims, but to make their voices heard and keep their images alive. Images that challenge the colonial discourse through which our narrative of nation has been woven.

\section{Keywords}

Marta Rodríguez, Latin American documentary filmmaking, documentary methodology, decolonization of the image, documentary film history.

\section{Marta Rodríguez, décolonisant la representation documentaire en Amérique latine}

\section{Résumé}

Dans cette conversation entre la cinéaste documentaire Marta Rodríguez et Pedro Pablo Gómez, avant d'entreprendre une tournée chronologique de l'œuvre de l'artiste, nous traitons les problèmes transversaux présents tout au long de son travail : le cinéma documentaire comme mode de représentation ; la construction d'une méthodologie du documentaire latino-américain; la nature décoloniale de l'œuvre de Rodríguez et son engagement pendant plus de quatre décennies pour accompagner les luttes des paysans, des indigènes et des Afro-descendants, entre autres. Et c'est dans cette approche que Marta Rodríguez, avec une mémoire extraordinaire, peut tisser une histoire qui souligne l'éthique de l'artiste et son engagement indécelable à dénoncer les injustices sociales, en utilisant les technologies du cinéma - pour ne pas parler en lieu des victimes, mais pour faire entendre leur voix et garder leurs images vivantes. Des images qui contestent le discours colonial par lequel notre récit de nation a été tissé.

\section{Mots clés}

Marta Rodríguez, le documentaire latino-américain, la méthodologie documentaire, la décolonisation de l'image, I'histoire du film documentaire.

\section{Marta Rodríguez, descolonizando a representação documental latino-americana}

\section{Resumo}

Nesta conversação entre a cineasta documental Marta Rodríguez e Pedro Pablo Gómez, não se trata de fazer um passeio cronológico pelo trabaIho da artista, abordam-se problemas transversais que estão presentes ao longo de sua obra: o cinema documental como modo de representação; a construção de uma metodologia do cinema documental latino-americano; o caráter decolonial da obra de Rodríguez e seu compromisso indeclinável durante mais de quatro décadas de acompanhar as lutas dos camponeses, indígenas e afrodescendentes, entre outros. E é nesta abordagem que Marta Rodríguez, fazendo uso de uma memória extraordinária, pode tecer um relato no qual se destacam a ética da artista e seu compromisso indeclinável de denúncia das injustiças sociais, utilizando as tecnologias do cinema, não para falar pelas vítimas, e sim para fazer ouvir suas vozes e manter vivas suas imagens; imagens que interpelam o discurso colonial mediante o qual se tem tecido nosso relato de nação.

\section{Palavras-chave}

Marta Rodríguez, cinema documental latino-americano, metodologia do documentário, descolonização da imagem, história do cinema documental.

\section{Marta Rodríguez, descolonizaco Representación documentaltal Latinoamericanata}

\section{Maillallachiska}

Kai parlope cineasta Documental Marta Rodríguez y Pedro Pablo Gomezua, Ñuspa ruraska sug kalpachii cronológico trabajomanda chi artista, abordareme problemakuna uikankuna presente paipa obrape, chi cine documental representacionsena; chi uiñachii sug metodología cine documental latinoameicanota, chi carácter decoIonial Rodriguezpa obra y paipa compromiso indeclinable chusku chunga uata compañerka lucha campesinokunata, nukanchigentekunata y afrodecendiente kunata, y sug kunatapas y kai abordagepe maipe Marta Rodríguez paipa iapa supa memoria iukaspa, auarka sug parlo injusticia 
socialkuna cinepe kauachispa, mana remangapa victimakunamanda, manakagpe uiangapakuna y iukangapa kaugsa imagenkuna, sug imagenkuna interpelankuna chi rimai colonial chiuak auarerka Nukanchipa rimai nacionmanda.

\section{Rimangapa Ministidukuna}

Marta Rodríguez, cine documental latinoamericano, metodología del documental, descolonización de la imagen, historia del cine documental.

Pedro Pablo Gómez: Leyendo algunas entrevistas que usted ha concedido anteriormente, me he dado cuenta que en la mayoría se indaga por los inicios de sus documentales para ir discurriendo de forma lineal en el tiempo hasta llegar a los trabajos más recientes Sin embargo, en esta ocasión quisiera proponerle unas preguntas de carácter transversal, para abordar temáticas importantes que son recurrentes en sus documentales. Por lo tanto, la primera pregunta es acerca del documental como un modo de representación. En "Chircales", su primera película, con todo el aprendizaje teórico y práctico que trae de Francia, usted ha dicho que busca una metodología de hacer el documental en las condiciones latinoamericanas. $Y$ es en estas condiciones, donde el concepto y la práctica de representación que usted realiza hacen que esa teoría inicial se vaya configurando en una concepción distinta de hacer documental como una práctica determinada por la realidad local.

Marta Rodríguez: Mira, cuando llegué aquí, con todo lo que aprendí en Francia con Jean Rouche, y los demás alumno de diversas partes del mundo, del Tercer Mundo: brasileños, latinos, africanos (porque él trabajó en África). Éramos tercer mundistas en ese pequeño grupo. Entonces Rouche nos decía: muchachos, ustedes aprendan de todo, porque en sus países - años 60 - no hay nada. Cuando de nuevo llegué a Colombia, efectivamente no había nada, absolutamente nada. Y entonces me encuentro con Jorge Silva. Y es un encuentro que es muy importante porque Jorge tiene un origen muy pobre, su madre es de Girardot, una empleada del servicio doméstico llamada Anita, quien murió de 90 años y tuvo una vida de sufrimientos como empleada de servicio doméstico, la explotaron, la tuvieron de esclava; en esos años las empleadas del servicio doméstico eran esclavas. Jorge nació en Girardot, y con tanta pobreza, su madre tuvo que venir a trabajar a Bogotá al Barrio La Candelaria como sirvienta. Jorge se crío en el Amparo de Niños porque los ricos, donde Anita trabajaba, no querian al niño molestando ahí en su casa; más tarde fue albañil. Entonces se da ese encuentro entre Jorge y Marta. Yo de la Academia, del Museo del Hombre de París, alumna de Jean Rouche, de la etnología. Jorge ya había hecho cine, había hecho un documental denominado Días de papel, que había hecho saliéndole del corazón, narraba su miseria y su infancia tan dolorosa. Entonces mira el encuentro: la academia y la realidad, que fue vital para la obra que hicimos. Jorge me dijo: sus teorías doña Marta, aquí se le van a volver añicos, allá en el Sur de Bogotá.

Es así como con Jorge Silva, nos vimos frente a la tarea de crear una metodología para América Latina. Primero, teniendo en cuenta que el que denuncia la violación de derechos humanos es amenazado. Por lo tanto, se requieren formas de entrar con "mentiras" bien dichas, porque para entrar a la hacienda, donde realizaríamos el documental Chircales había que pedir permiso a los capataces, a los dueños, los Pardo Morales que eran unos fascistas terribles. Ellos estaban afiliados al Partido Conservador y eran fascistas. Eran dueños de una propiedad que venía desde el sur de la ciudad hasta Barro Colorado (en las inmediaciones de la actual Universidad Javeriana de Bogotá). Uno no entraba a la hacienda sin permiso. Entonces era toda una estrategia: a uno de ellos me lo presentó un periodista francés, que le dijo que yo había estudiado lingüística y que iba a hacer un trabajo lingüístico; por eso me dieron permiso. ¿Entonces qué pasa adentro? Cuando nos ven, al principio, los viejos como incómodos porque dos personas con una cámara. Y al llegar nos encontramos con una comunidad casi a nivel de analfabetos, trabajando como esclavos en la fabricación de ladrillos. Y llego yo con una máquina grande que graba imágenes. Eso era magia. Era magia que yo llegara a reproducir imágenes de ellos. Entonces se creó allí un mundo fantástico con unas historias increíbles. Pero Jorge y yo empezamos a sufrir una represión desde que llegamos. Fue entonces, cuando yo le decía a Jorge, estamos creando una metodología para América Latina.

Se encuentra uno con una sociedad que viene de La Violencia de 1948. La primera vez que 
Camilo Torres me llevó a mi escuelita dominical a Tunjuelito donde eran barrios de invasión, veníamos de esa violencia. Gente que llegó de Boyacá, de Cundinamarca, de todo lugar de donde emigró la población. Y como son personas poco calificadas, entonces, a hacer ladrillo. Era un trabajo esclavista totalmente, con mano de obra regalada y esclava; no era sólo que fuera barato, eso era esclavitud. Todo eso crea un universo en el que la comunidad se va a transformar. Porque cuando llegan dos con esa magia que es el video, se genera un proceso que no para. La comunidad se transforma ante las preguntas: ¿Ustedes por qué no tienen prestaciones sociales? ¿Por qué tienen que obedecerle así al patrón? ¿Y ustedes por qué están aquí de esclavos? Y claro, los viejos nos vieron y cuando vieron la grabadora dijeron: pa' afuera, pa' afuera. Y empezó la persecución. A mí me hicieron un atentado a bala una noche que venía del Mogador, una sala de cine, y frente al Planetario me dispararon dos balazos. Además, mandaban gente a mi casa disfrazada de empleados de la empresa de teléfonos a amenazarme, llamaban a decirme que me iban a demandar y de todo.

PPG: Y todo eso porque les estaba quitando a "los esclavos".

MR: Sí. Entonces te das cuenta lo que genera eso. Y lo que genera la presencia de equipos de grabación, porque eran cámaras pequeñas, como la cámara Bolex, que es una cámara que tiene un carrete de pequeño formato, cien pies, que dura dos minutos y medio y no más. Allá no había luz eléctrica, eran unas montañas. Entonces uno le daba cuerda a la cámara, ponía su rollito y grababa. Bien utilizado, dos minutos y medio en cine es mucho, porque hay cortos de dos minutos. Entonces, como yo había aprendido acerca de la observación participante, con Flaherty; yo llegaba con la cámara cargada, me quedaba todo el día, por ahí me quedaba con ellos viendo cómo cargaban los hornos y filmábamos todo. Nunca pusimos en escena nada, como llegar a decir: "mire tome esa escalera y ponga cara de que está cansado," no eso jamás. Era captar el gesto, pero pasábamos todo el día. Aunque yo no tenía equipo, la televisión que inauguró Rojas Pinilla, que en esos años quedaba en la calle 45 con carrera 13 , me prestó los equipos; me dieron cámaras, laboratorios blanco y negro gratis. Recogía la cámara a las ocho de la mañana y la entregaba a las cinco o siete de la noche, cuando volvíamos. Y estábamos todo el día allá, en unas condiciones difíciles. Luego compramos una Bolex cuando nos fue tan bien con Chircales, una Bolex más profesional, más grande, que tenía un motor y sincronizaba la imagen con el sonido. Pero la primera vez fue, como aprendí en Paris, con cámaras pequeñas y el sonido lo hacía aparte, con una grabadora que me vendió un suizo que vino a entrevistar a Camilo Torres.

PPG: Uno se pregunta cómo ustedes en esas condiciones tan precarias logran hacer una obra maestra como Chircales. Se podría pensar que la técnica o la alta tecnología no garantizan la calidad de la obra y que, por el contrario, en condiciones precarias es posible hacer una gran obra pues se trata, entre otras cosas, de la calidad de las imágenes que depende del ojo del camarógrafo. MR: Mira si tú tomas el cine político de los 60 , todo lo que es el cine político de Brasil, Chile y Argentina, te das cuenta que está hecho con la cámara de combate que era la Bolex, la misma que yo usaba. Ese cine es de una grandiosidad que jamás te lo va a dar, toda la revolución tecnológica del cine de ahora. Porque a veces se llega al facilismo. Mira, yo que doy clase, a veces los chicos y aun los indígenas a quienes les damos un taller de guion, cuando les digo hagan un proyecto el resultado parece radio, porque dicen bueno, entrevisto a este, entrevisto a aquel. $Y$ yo les digo: No, son imágenes.

PPG: Para mi trabajo de investigación yo hice el ejercicio de transcribir los diálogos de todas sus películas, y en ese proceso me doy cuenta que algo que caracteriza su trabajo en general, es su capacidad de dejar hablar al otro sin caer en la práctica hegemónica de tomarse el derecho de hablar por ese otro, llámese campesinos, indígenas o afrodescendientes.

MR: Darle la voz al otro.

PPG: Y cuando le da la voz lo deja hablar y desarrollar sus propias ideas y pensamientos.

MR: $Y$ aun muchas veces no eran entrevistas. Por ejemplo, uno veía que surgió algo, un hecho, por ejemplo a Alcira, la hermana mayor en Chircales, la encuentro llorando una tarde. Y surgía así porque yo no estaba preguntando: ¿Que hubo Alcira por qué está triste? No. Entonces es ella misma que me dice es que mi mamá está embarazada otra vez doña Marta ¿Yo qué hago? Lo hacía de una manera 


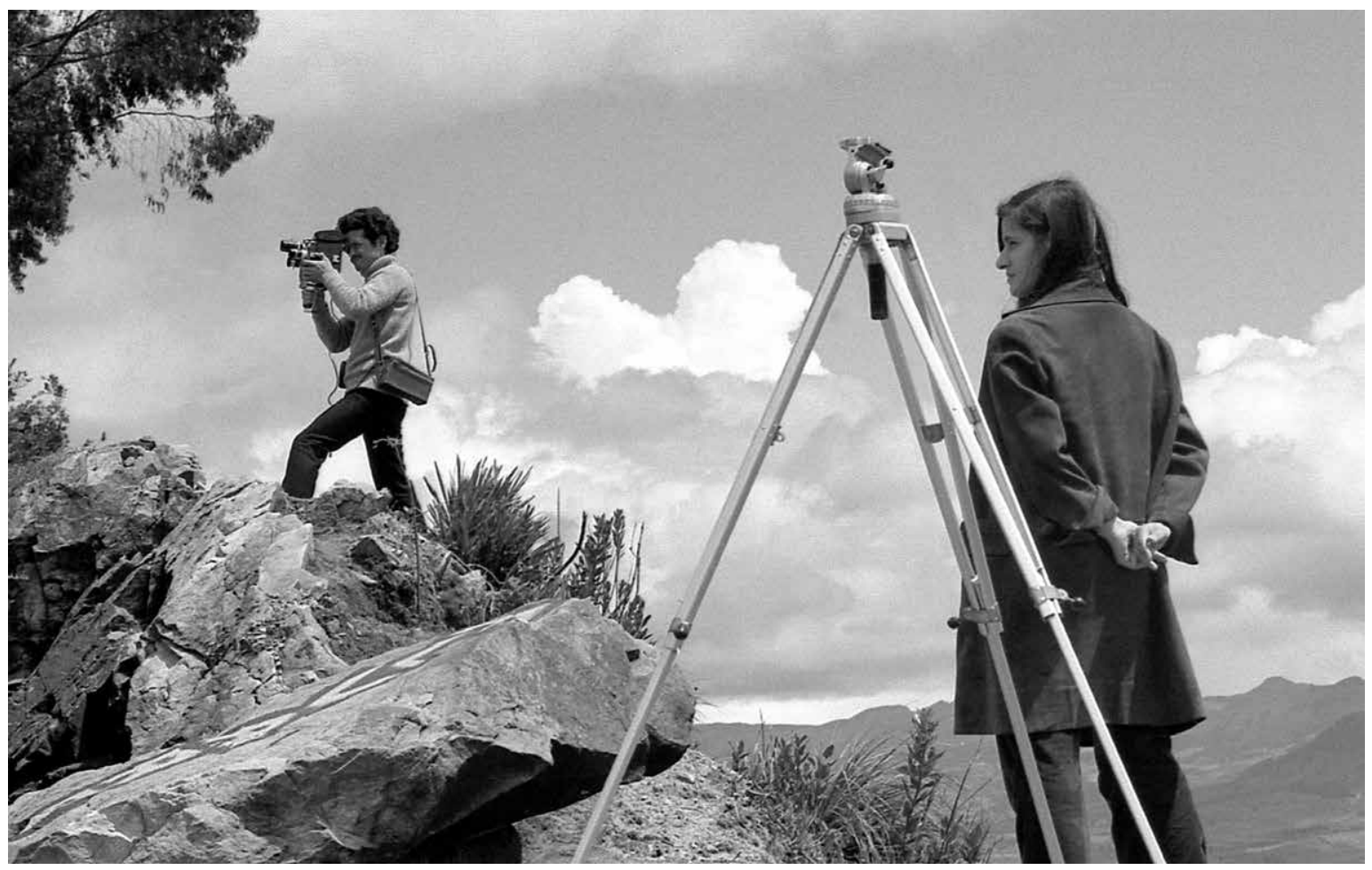

Marta Rodríguez y Jorge Silva en el rodaje de Campesinos (1970-1975).

completamente espontánea, no era que yo iba a decirle cuénteme. No. Porque yo vivía allá con ellos, y aunque yo quise vivir todo el tiempo con ellos, los viejos no dejaron. De todos modos, llegaba a las ocho de la mañana y me iba por la tarde, a las siete, cuando ya estaba oscuro, yo estaba todo el día allá.

PPG: Y esa es la investigación participativa, colaborativa, que no consiste en hacer un proyecto "sobre" sino "con" ellos.

MR: Con ellos. Y eso se fue prolongando con los demás grupos.

PPG: En ese sentido, es interesante saber ¿cómo ha sido el cambio para de trabajar con los campesinos de Chircales a trabajar con el Concejo Regional Indígena del Cauca, CRIC?

MR: Mira, pasar de trabajar con el campesinado migrante, en una zona suburbana, campesinado que venía de la violencia del 48 , que sus valores eran el Partido Liberal oel Partido Conservador, la magia de todo lo que es la religión, la virgen con el manto azul, Por qué somos liberales, por la sangre que se derramó en la guerra, ese era el imaginario de Alfredo Castañeda en Chircales. Pero llegas al Cauca, y te encuentra una gente que tiene a Quintín Lame, La Cacica Gaitana, Juan Tama, entre otros, con una historia de lucha desde La Conquista, que tienen un pasado histórico, entonces eso es otra película. Nos nombraron un comité como de ocho líderes para que estuvieran de asesores del documental, Nuestra voz de tierra memoria y futuro. De otra parte tener Campesinos que fue un proyecto alterno, cuando terminamos Chircales llegó el escritor Arturo Alape con esa idea. Yo quería hacer Gamines, teniendo como material lo que Jorge vivió en la calle y conoció en ese mundo. Y Alape dijo que él quería hacer un documental sobre la lucha campesina de los años 30, allá en la zona del Tequendama, y por eso lo hicimos. Pero también estaba el movimiento agrario de los años 80 , el movimiento de recuperaciones de tierras. Fue así como Campesinos se editó con estos dos momentos históricos. 

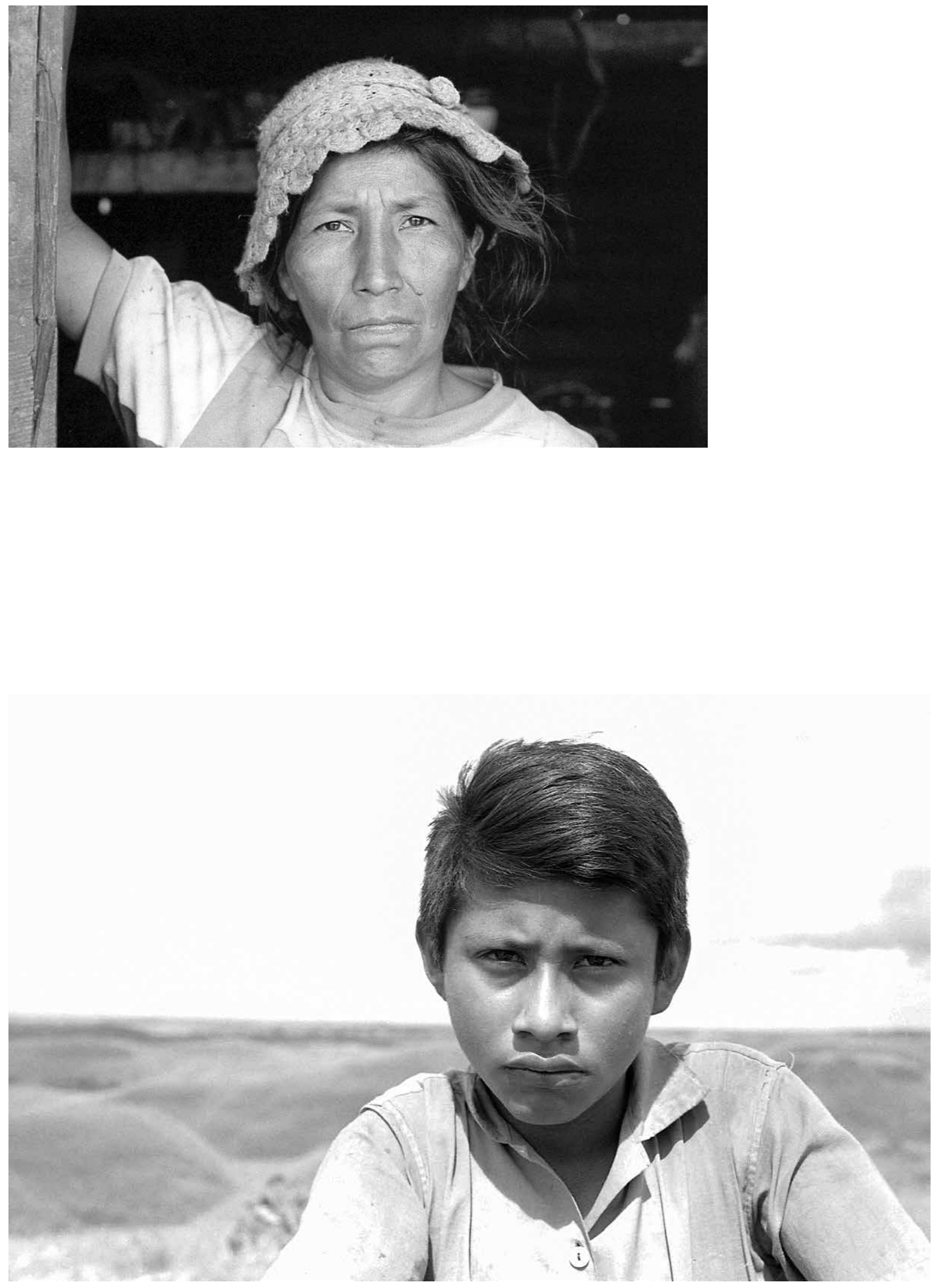

Arriba: Gertrudis de Lame, esposa de Justiniano Lame, líder asesinado. Nuestra voz de tierra memoria y futuro (1974-1980). Abajo: Luis Alberto Quintero en Planas (1971) 
PPG: Al comienzo de Campesinos hay una secuencia que de alguna manera anuncia el trabajo con el CRIC.

MR: Campesinos es un relato de un campesino de Villa Rica, Tolima. Sobre todo, se hizo de Villa Rica con imágenes de mujeres en el Cauca recuperando tierras.

PPG: Lo interesante es, como usted lo ha dicho en otras ocasiones, que el guion que presentó Arturo Alape fue transformado por los mismos campesinos.

MR: Es que ellos eran los que tenían la memoria de las luchas de los años 30, porque eran gente mayor, sabían las canciones, hicieron instrumentos como los cepos, elementos de castigo; en otras palabras, ellos dirigieron la película. Y nos decían, miren don Jorge y doña Marta, vamos a filmar tal cosa, vamos a filmar cómo recuperábamos la tierra en ese momento, con colinos de plátano crecidos grandes; la matica de café ya crecidita, hacíamos lo que decían ellos. En cambio, en el Cauca seguíamos el proceso de un programa que incluía las tareas de recuperar las tierras, las historias, la cultura, la educación. Y nosotros seguimos el proceso de cualificación política, como escribió Jorge en un artículo sobre la película, Nuestra voz de tierra, memoria y futuro, que se trataba de pasar de la sumisión a la organización. En más de cinco años vimos cómo ellos se iban cualificando políticamente. Lo del Cauca fueron entonces casi seis años, algo muy extenso.

PPG: Trabajos extenso con el CRIC. Bien, en su trabajo uno encuentra tres sujetos colectivos con los que ustedes colaboran: los campesinos, los indígenas y los afrocolombianos. ¿Sin embargo, podría decirse que hay un énfasis en el trabajo con los indígenas?

MR: Mira yo empecé porque en los años 70 un compañero de Camilo Torres, Gustavo Pérez Ramírez, que era también sociólogo de la universidad de Lovaina y quien trabajó mucho en los medios, creó la primera empresa de cine aquí, El Instituto de Investigación social, ICODES ya con todo. Aquí no había empresas de cine, no había nada. Él trajo moviolas, salas de edición, se ubicó en el centro, por La Candelaria. Y fue entonces cuando el vino a la Universidad Nacional a denunciar una masacre en San Rafael de Planas, en el Vichada. Y hacemos Planas: testimonio de un etnocidio. Y cuando yo veo la barbarie con los indígenas, cómo los llaman irracionales, cómo los masacran y los torturan, que eso es un escándalo en cualquier parte del universo, yo ya me quedé comprometida con el movimiento indígena hasta hoy.

PPG: Claro ese es el primer momento. En esos días se publicó también el libro de Gustavo Pérez, "Planas: las contradicciones del capitalismo." MR: Si, trabajamos con él. Gustavo Pérez fue quien la produjo, porque tenía esa empresa, el ICODES, con salas de edición. Yo edité Chircales en mi casa, con una moviola que compré en Francia que era una pantallita a mano. $Y$ venía la familia de los Castañeda, yo les decía a ellos, ¿les parece bien que edite religión con trabajo? ¿Qué piensan? Y venían aquí y miraban todo.

PPG: La familia de los protagonistas de Chircales. ¿Y vinieron a esta casa también algunos de los protagonistas de Planas?

MR: No, a los de Planas nos tocó sacarlos. Porque al chico que torturaron, Luis Fernando Quintero, lo estaban persiguiendo para desaparecerlo, para que no dijera que lo habían torturado. Entonces tocó traerlo a Bogotá, con doña Cecilia que era como la abuela. El líder Isaías Gaitán y un niño de suyo vinieron aquí, porque habían hablado en guahibo y tocaba traducirles. $Y$ aquí se quedaron como dos semanas. $Y$ en el estudio de ICODES hicimos las últimas secuencias, porque el chico que torturaron no quería hablar, estaba traumatizado, lo habían colgado de los testículos, le pusieron corriente en el cuello. El padre lo llevó donde un médico porque él estaba muy preocupado por todo lo que le hicieron. Yo me gané su amistad poco a poco, viviendo aquí, conviviendo con él, hasta que aceptó dar la entrevista.

PPG: Con base en todo esto, sale esa conclusión, después del fallido debate en el Senado, que afirma que para los indígenas no hay ley. Pues esa lucha de los indígenas por sus derechos por la vía legal era muy difícil, y en términos políticos estaba bloqueada.

MR: Y aun hoy día.

PPG: De todos modos, los indígenas, le apostaron a esa vía legal, en un lento proceso, hasta llegar a la Constitución de 1991.

MR: Claro, y ahora tienen la consulta previa que no existía antes. Por ejemplo, a los Kankuamos 
que les mataron 300 personas, tienen medidas cautelares y aunque no se han implementado completamente ya eso es algo distinto. Corte Constitucional hizo un estudio y mediante el Auto No. 004 de 2009, declaró que 35 comunidades están en peligro de extinción. Entonces, ahora sí hay una vigilancia y está la consulta previa y las medidas cautelares.

PPG: La Corte hace un fuerte llamado al gobierno para que tomen medidas frente a los riesgos detectados en ese estudio.

MR: En El Llano cuando hubo una masacre de los Cuibas, a mí me tocó el juicio en Villavicencio. Eso fue debido a que los indígenas eran nómadas y a veces cogían una ternera o algo, y los llaneros que los odian, terminaron por masacrarlos. En ese caso, fue que invitaron a una comunidad y la masacraron, pues les dieron un sancocho que tenía sal con cianuro. Además, los quemaron con gasolina, a ancianos, niños y jóvenes. Uno de ellos se voló y denunció en Villavicencio, yo estuve en el juicio. $Y$ en aquellos tiempos absolvieron a los denunciados. Esto, porque matar en el llano no era delito, as era, matar indios no era delito. Pero cuando llega la Constituyente cambió todo.

PPG: Al menos dos miembros de las comunidades indígenas fueron miembros de la Asamblea Constituyente de 1991.

$\mathrm{MR}: \mathrm{Si}$, estaba Lorenzo Muelas, guambiano, y el amigo que está preso, Francisco Rojas Birri, embera.

PPG: Otra pregunta. En ese proceso de "dejar hablar a los otros" vemos que la voz en off va siendo cada vez menor se va poniendo entre paréntesis. MR: Si correcto.

PPG: Al comienzo había una voz en off larga que daba un panorama contextual y conceptual muy amplio.

MR: En Chircales tocaba explicar. Solamente lo didáctico, relaciones de producción, procesos tecnológicos, lo esencial.

PPG: Pero cuando uno mira los últimos documentales se da cuenta que la voz en off se utiliza cada vez menos, porque además de dejar hablar a los otros las imágenes mismas adquieren un carácter explicativo.
MR: Nuestra Voz de tierra memoria y futuro, tiene muy poco uso de la voz en off, de pronto entra otro locutor, como para cuando es necesario el mito se escucha la voz de Lucy Martínez.

PPG: Hay un profesor indígena, Manuel Cisco que, en Los hijos del trueno, cuenta de una manera extraordinariamente didáctica el mito de la tierra, del cuerpo tiene la tierra. ¿Recuerda a esa persona?

MR: Ah, Manuel Cisco. Ahora que estuve en el Cauca, lanzaron la política de medios y me encontré con todos mis viejos amigos. Y llegó Manuel Cisco, médico tradicional de The Wala, de la comunidad Nasa.

PPG: Es evidente su conocimiento de sanación, pues él habla de la enfermedad de la tierra y cómo curarla. Y más adelante proponen que hay que amarrar la tierra para evitar los deslizamientos, en contraposición a los conceptos de los geólogos. MR: Sí, porque ellos, los Nasa, pensaban que los querían sacar. Entonces decían nos echan esta carreta es para sacarnos. Por eso hacen el ritual.

PPG: Hay tres videos en los que se cuenta un mito, en Nuestra voz de tierra memoria y futuro, el mito de la huecada, en La Hoja sagrada, el mito del pischimisak, en Los hijos del trueno. Lo interesante es cómo la estructura del mito se va entrelazando con la historia para hacernos entender que en esa relación entre mito e historia lo que se va configurando finalmente es el proceso de recuperación de la memoria.

MR: Si claro.

PPG: $Y$ es porque ellos se paran en el mito, porque si se apoyaran en la historia no habría ninguna subversión de la narrativa de la historia. Esta práctica decolonial de la historia, a mi modo de ver es posible porque se parte del mito.

MR: Si, allá en el Cauca, cuando escuchamos el mito de la huecada, eso va a repercutir en que muchos se fueron de la finca, Porque cuentan que se aparece como diablo, como terrateniente, y como carabinero. $Y$ entonces de noche vuelve a la hacienda y sienten que camina con zapato de material, como dicen ellos. Y por la noche asustaban porque esa era una hacienda mágica " y quedaba arriba, allá en Puracé y eso era pura neblina. Entonces de noche se sentían los pasos y era 


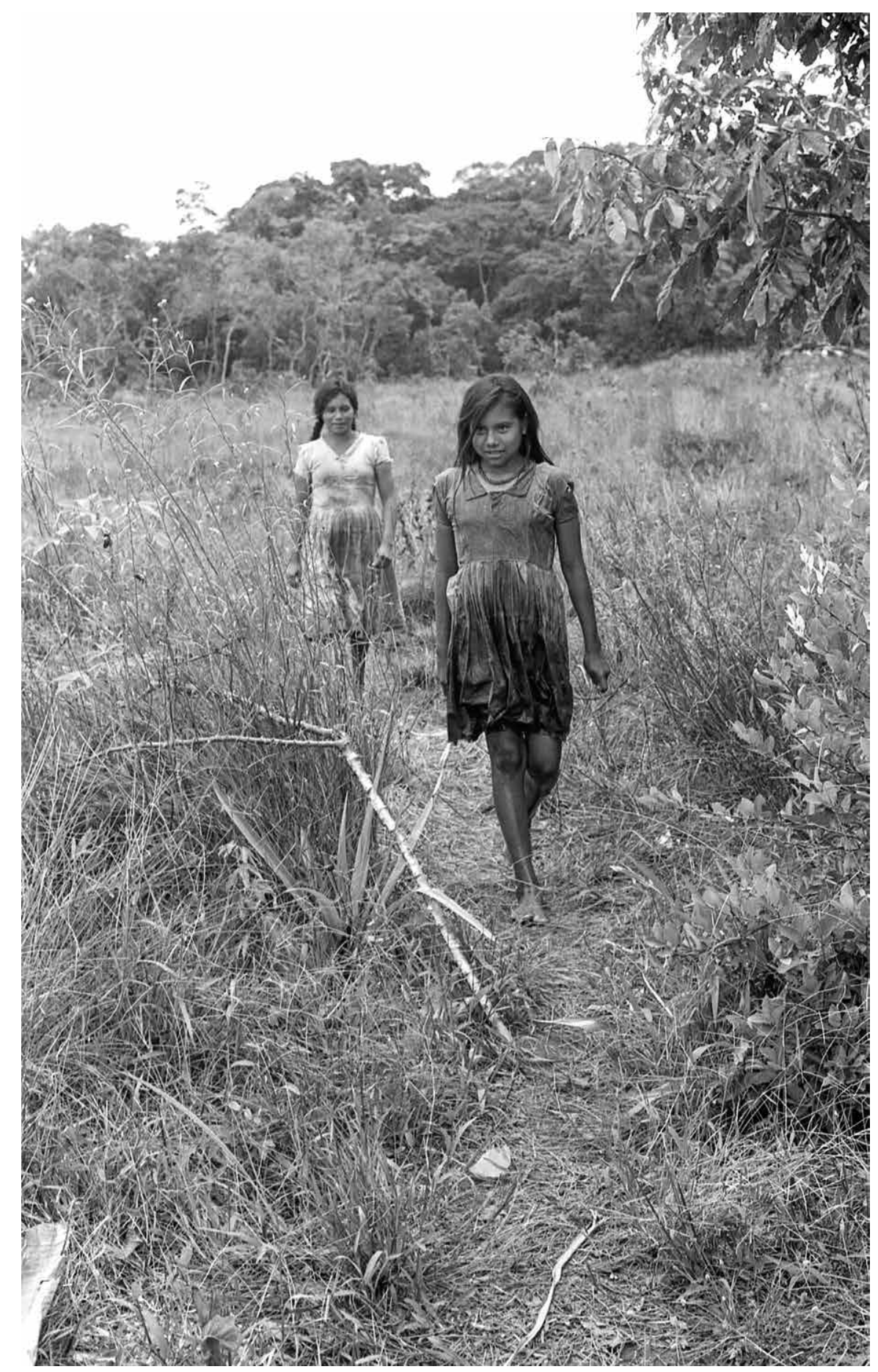

Planas (1971) 
porque el terrateniente quería volver. Entonces, se moría gente así de pronto, se moría.

PPG: Esa es la estrategia del miedo y del terror que utilizan los terratenientes.

MR: Y se fueron muchos del miedo.

PPG: Por eso, por ejemplo, como dice en otra parte Jesús Piñacué: "es que no podemos dejar que el miedo nos gane."

MR: Claro, cuando matan en la hacienda Nilo, en Caloto Cauca a los veinte hermanos indígenas, hay una frase de Jesús Piñacué que dice "que el dolor, la miseria y el abandono, no sea la peor enemiga de nuestro pueblo; que todos tenemos que empezar a pensar con valor en la necesidad de construir un Cauca de paeces y guambianos en el que se pueda convivir, en el que podamos encontrarnos todos como hermanos. Pero aquí estamos compañeros, y vamos a seguir avanzando, no lloremos nuestros muertos simplemente, suframos, pero recojamos del valor y la verraquera de estos hombres para que nosotros hagamos de nuestro espíritu un fuego capaz de construir un Cauca mejor."

PPG: Es claro cómo esa recuperación de la memoria es una lucha contra el miedo y contra el olvido. MR: Y también la rabia. Cuando Piñacué dice, que miró a los muertos, desnudos, con heridas impresionantes, sin brazos, sin piernas, otros sin rostro. $Y$ después cuando los sacaron en los ataúdes en esa fila, era tanto el odio, dice, que él prefería alimentarse de cada una de las estampas de rabia y de dolor que sentía una víctima ahí en un ataúd, porque son ataúdes que tienen un espejo, un vidrio transparente, el rostro puede ver uno. Y una mueca de angustia, de desesperación de un indígena que solamente quería tener un pedazo de tierra, tener que morir de esa manera. No es justificable en ningún caso.

PPG: Por otra parte, Margarita de la Vega, en un ensayo, propone una serie de características de su trabajo, entre ellas la larga duración de los proyectos. Eso tiene que ver por una parte con los procesos de investigación, y por otro, en alguna entrevista Jorge Silva dice que obedece a las circunstancias. Por eso la pregunta es si les hubiera gustado enfrentarse a procesos más cortos y hacer una mayor cantidad de películas.

MR: Cuando se mira la tecnología que usábamos es una cosa. Pero cuando uno mira una comunidad de terrajeros, siervos de la tierra, que luchan por no pagar terraje, porque eran muy pobres, porque era pobreza, pobreza. Eran como esclavos de las haciendas y al cabo de cinco años recuperan las fincas, crean empresas comunitarias, es otra cosa, eso lo aprendimos en cinco años. Si yo voy ahora con una cámara de video que me graba imagen y sonido y me meto a un computador y listo, ya edité, porque ahí todo lo hace solito. Yo creo que en ese cine grandioso de América Latina influyó la tecnología, uno tenía que meter muchos años de trabajo. Por ejemplo, editando Nuestra voz de tierra memoria y futuro, fue un año entero aquí, y en Cuba como seis meses. Y venía el músico Jorge López del grupo Yaki Kandru, él tenía un grupo musical indígena, había estudiado antropología y venía todas las tardes a hacer la música. Entonces son procesos que seguíamos, el Movimiento agrario que duró diez años entre los setenas y ochenta y salen tres películas: Campesinos, Nuestra Voz de tierra memoria y futuro y La voz de los sobrevivientes, que son tres documentales del movimiento agrario, entonces son diez años en total.

PPG: Otro aspecto, que a mí me parece que a Margarita de la Vega le faltó, es una característica y es el carácter de corpus que tiene su trabajo no como unidad cerrada sino abierta, un trabajo que tiene una coherencia interna. Aunque se podría decir que Nacer de Nuevo se sale un poco del contexto político porque es una crónica poética, mucho más humana. Pero al mismo tiempo entra en ese corpus porque se trata de la realidad nacional de la víctimas de la avalancha que desapareció a Armero, en este caso son víctimas de la naturaleza, pero también de la falta de prevención, pues que incluso la explicación de la causa del desastre la señora María Eugenia la atribuye a una castigo divino; lo interesante es que en ese documental usted no se va a buscar la imagen fuerte de barro que ahoga a las personas sino una imagen poética de vida.

MR: Es que los armeritos no querían ver ciertas imágenes. En muchas villas armeritas que se crearon, nosotros empezamos a mostrar y ellos no querían saber nada de imágenes de barro. Pero cuando les digo, no, el documental se trata de una viejita que se enamora de un viejito, entonces sí accedieron. Para muchos es la película que más les gusta de Marta. 
PPG: Es porque hay una especie de guiño hacia una especie de ficción o mejor a una realidad con carácter mágico y poético a la vez, aunque no se origina en un evento trágico.

MR: Es que tenía un personaje que era mágico. La viejita era mágica, llegaba al campo santo y hablaba con los muertos, hablaba con los animales, con su gallina, sus perros y su yegua. Y le cantaba a la gallinita por la mañana. $Y$ era en esa soledad y en esa tristeza que mucha gente quedó perturbada mentalmente porque perder la familia, todos los bienes materiales, tú te imaginas. Mucha gente se enloqueció o se metían con el alcohol, fue terrible ese drama. Y la viejita siempre bien arreglada bien bonita con un humor increíble, quería vivir cien años para recuperar todo lo que había perdido en la avalancha.

PPG: Ella tenía una concepción de la memoria y de la vida muy optimista a pesar de todo.

MR: Si, a pesar de todo.

PPG: Esa película, a mi modo de ver, hace un corpus con las demás porque hay elementos recurrentes que las relacionan. Uno podría, por ejemplo, visualizar en un ensayo el problema de los niños en el trabajo de Marta Rodríguez, empezando por los niños de Chircales, los niños de Planas, hasta llegar a la niña Maryi Vanessa Coicué en No hay dolor ajeno. El problema de los niños atraviesa su obra porque ellos han estado presentes en las luchas y han sido víctimas de la represión. No hay que olvidar que indígenas mismos han sido considerados por el discurso colonial como niños. Otra imagen poderosa es la de una niña en el rescate del terremoto del rio Páez, entonces uno puede hacer un recorrido y encontrar que los niños siempre han estado ahí en sus películas, en medio de las luchas sociales.

MR: Y la última, en la que es la muerte de Maryi Vanessa Coicué, ¿esa cómo la vez?

PPG: En este momento la veo como el punto culminante de su obra. Me parece que muestra cómo la violencia en Colombia adquiere una diferenciación por edades, así como también los problemas sociales tiene estratos y edades y geografías.

MR: Cuando el padre de Maryi Vanesa dice que no mueran más niños, que mueran en su cama, mayores, pero que no mueran más niños. El discurso de Abel Coicué es magistral, político y estremecedor.
Las armas matan y son más racionales los animalitos que cuidan sus crías y que creemos irracionales, los cuidan más de los que tenemos raciocinio. El interés en esa película es porque el personaje Abel, el padre de Vanesa, yo lo conocí en la Universidad del Valle en un encuentro de víctimas, recién le habían matado su niña de once años. $Y$ era tal la dignidad, la dimensión del personaje que yo le dije, yo le hago la memoria de su niña. Y sí, me mandaron todo el material que habían grabado y aquí lo edite con Fernando Restrepo. Y hace poco estuve con él, y él dice que lo está amenazando la guerrilla, que quieren asesinarlo porque él dijo que no descansaría hasta que la guerrilla responda por lo que hicieron a la niña. Entonces él dice, "yo fui a hablar con ellos a decirles que me mataron mi hija, a lo que responden que qué pena, que lo sentimos, pero que ese tatuco era para usted que jode tanto denunciándonos. Pero mire el cinismo de la guerrilla al decir que el tatuco era para usted." ¿Qué piensas tú de semejante cinismo? $Y$ ahora que fui en diciembre yo estuve hablando con Abel y él está todo destrozado llorando, porque le quedó un hijito, y él no puede ir a la vereda donde vive porque la guerrilla lo tiene amenazado.

PPG: El Tema de las mujeres ha sido muy importante en el Cauca y en sus películas; desde la cacica Gaitana, hasta lideresas como Aída Quilcué, la señora Gertrudis, esposa de Justiniano Lame y la misma Maryi Vanesa que era una futura líder. MR: Ella quería ser líder era una de las mejores alumnas.

PPG: Eso pone a pensar que el genocidio ha sido históricamente selectivo, aunque en este caso aparentemente es accidental, pero ha sido selectivo apuntando a los líderes.

MR: A la niña que era la mejor alumna, que quería ser líder, mira si tienes razón. Y las mujeres en el Cauca han tenido un papel vital. Aida Quilcué, la Gaitana, entre otras, allá hay líderes mujeres que son una maravilla. Y la niña en pleno, abriéndose a la vida, a los once añitos la fulminan con un tatuco ipor Dios! Yo lo hice, y lloré mucho en ese video. Yo no edité las imágenes más duras, porque era muy duro, la niña la pusieron en la mesa y tenía las piernitas llenas de heridas por las esquirlas y todo. Yo quería poner una imagen, pero como edito con Fernando, que es una persona que no puede ver 


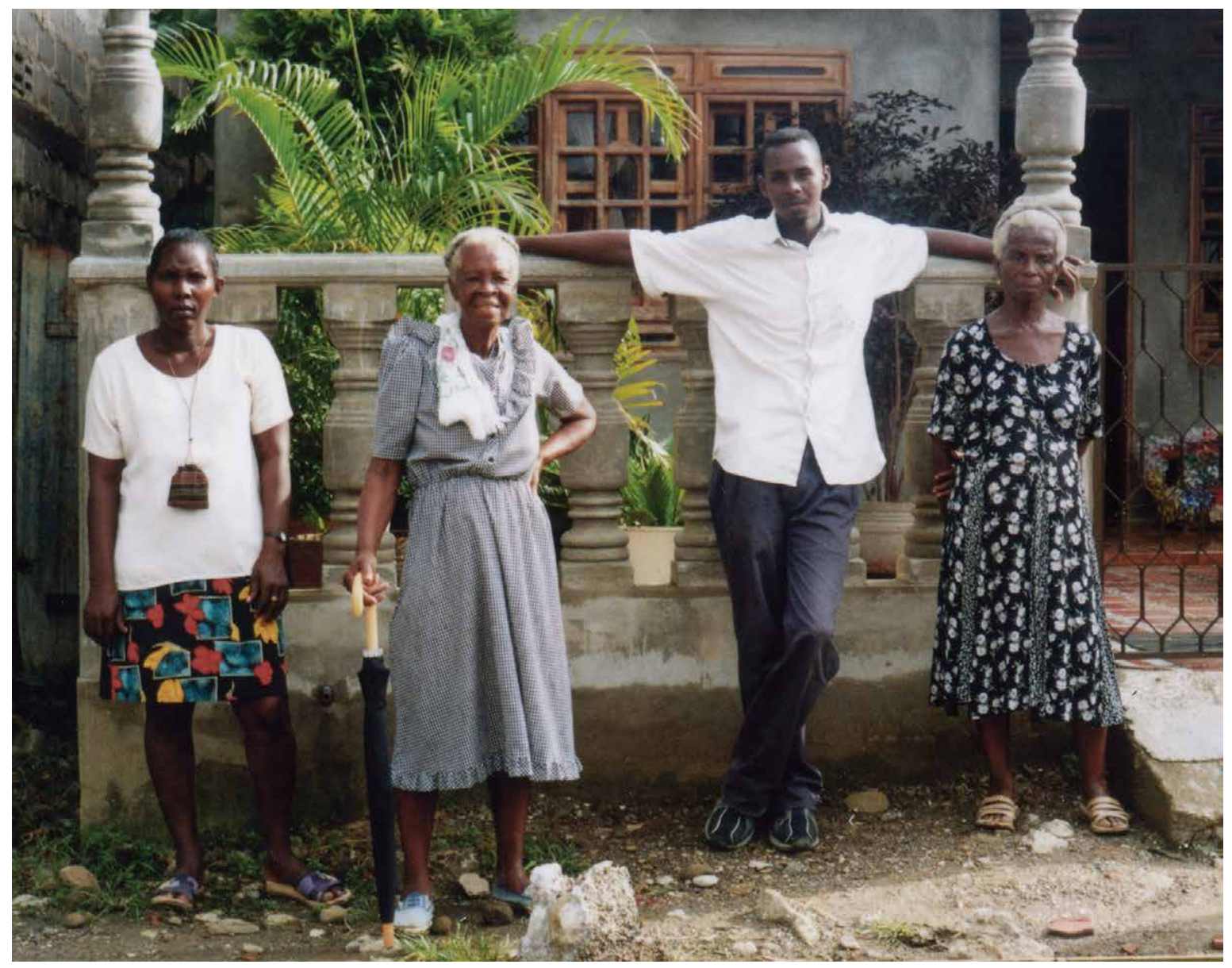

Una casa sola se vence (2003-2004).

un muerto, el no quiso ponerla. Luego le digo así, y él dice que es demasiado fuerte.

PPG: Alli hay un componente importante que tiene que ver con hasta dónde llega la colaboración con los indígenas, hasta el punto que buena parte del material es grabado por ellos mismos.

MR: Todo es grabado por ellos, a excepción de la entrevista que le hice a Feliciano Valencia en Barrancas en un Encuentro Campesino. Todo lo demás y lo de las escuelas lo consiguió Fernando en la Internet.

PPG: Allí se puede ver cómo los indígenas se van apropiando de la tecnología, y se podría pensar en cómo es el documental hecho por ellos mismos. MR: Ellos han hecho obras muy bellas, y han tenido premios en varios lugares, por ejemplo, Somos alzados en bastones; han hecho obras preciosas como la de la minga que es un trabajo hermosísimo. Esto es un trabajo bien bonito porque es apoyar al Tejido de Comunicación Nasa en un drama que se está viviendo en el Cauca, que es la muerte de los niños, que está ocurriendo con mucha frecuencia, con demasiada frecuencia.

PPG: La semana pasada había amenazas en ese sentido.

MR: Sí, yo tengo como 15 niños grabados para hacer un documental. En la semana de la memoria histórica que hubo un día dedicado al Cauca, vinieron del Cauca y están haciendo una cosa preciosa, están creando orquestas en memoria de los niños, crearon Huellas, una sinfónica, y vinieron los niños con las fotos de cada niño muerto en memoria de ellos. Cantan canciones. Voy a hacer un gran 
trabajo sobre eso; es mi próximo proyecto, si se puede.

PPG: Hay una secuencia en Los hijos de trueno, en la que una profesora a la que le cayó encima una pared de la escuela durante el terremoto; en esa secuencia, los niños cantan una canción que se llama "vasija de barro," pero lo hacen en su propia lengua, y cantan otra que dice que "para el indio nunca hay paz," algo muy conmovedor.

MR: Si tú vas a San Andrés de Picimbalá ellos hacían entierros secundarios en vasijas de barro, ponían los huesos en vasijas de barro, de ahí viene el sentido de todo eso.

PPG: Claro y es que es una concepción muy arraigada debido a la pertenencia del indígena con la tierra.

MR: Si, como dice Abel, que Maryi Vanessa va a volver a la madre tierra, que la devolvemos a la madre tierra. Abel es un personaje extraordinario que trabaja en el Tejido de Comunicación en la radio, y está muy comprometido con el Tejido. Él empezó a denunciar a la guerrilla hace mucho tiempo, por eso le cayó el tatuco en su casa.

PPG: Le planteo lo siguiente para saber su opinión, teniendo en cuenta que el texto que estoy planteando tiene como base teórica las categorías elaboradas por el grupo modernidad/colonialidad, Quijano produjo un concepto denominado la colonialidad del poder, y su distinción entre colonialismo y colonialidad. Como sabemos, con el mal Ilamado Descubrimiento de América, empezó a actuar la colonialidad del poder, y enseguida de la conquista violenta, se inició la colonización del imaginario, de los modos de conocimiento y expresión simbólica de los pueblos. Pero al mismo tiempo iniciaron las luchas de parte de los vencidos por la descolonización, la cual no se realizó con las independencias americanas en el siglo XIX, sino que continua hoy en día; una lucha que es epistémica, estética, política para la cual es clave la descolonización del imaginario. Así, lo que yo veo en su trabajo, es que va en la vía de la descolonización del imaginario, en las luchas de las comunidades indígenas, afrodescendientes y, por decirlo así de los de abajo en general. De ahí, la importancia de los mitos y de la construcción de una historia propia para los indígenas, y no tanto el interés de insertarse en un relato nacional, por el contrario interpelar ese relato nacional al que nunca fueron completamente integrados, o si lo fueron, lo hicieron como sujetos subalternos en el relato de la colombianidad.

MR: Eso se vio acentuado en 1992, cuando se dio lo de los 500 años. Los indígenas dijeron vamos a responder con el auto-descubrimiento. Yo participé mucho en esa etapa porque ellos dijeron vamos a recupera todo lo que son las tradiciones, los mitos, los rituales, las memorias, todo y publicaron muchos libros. Eso fue la respuesta a los 500 años, diciendo nosotros nos vamos a auto-descubrir, todos los viejos que tienen los mitos, los rituales, las fiestas, las luchas y fue un trabajo precioso que hicieron y que continúa hoy en día. A partir de allí era lo que yo escribía. Hubo una afirmación étnica muy importante y en esos días llegaron aquí brasileños, ecuatorianos, de todos los países de América Latina, y nos reunimos aquí en Bogotá, pero también en México y en Brasil. Aquí muchos decían, yo no sabía que había aymaras y quechuas, pero claro que había, aunque muchos de ellos estaban allá en sus montañas.

PPG: Y quizá en parte por ese proceso de autoafirmación es que ahora son tan fuertes los movimientos sociales conformados por comunidades indígenas y afrodescendientes en Ecuador, en Bolivia y aquí mismo en Colombia.

MR: Mira la fuerza que tiene ahora, de todo lo que han logrado. Y eso partió de esa etapa del autodescubrimiento y de la Constituyente que hoy es como la vanguardia de los movimientos en América Latina, todos los movimientos indígenas.

PPG: ¿Podemos conversar un poco más?

MR: Sigamos, porque yo no me canso. Porque felizmente no estás buscando cronologías, ni cuenticos, ni cómo hizo esto o aquello, sino un análisis más profundo, se me hace estupendo que tengas una teoría planteada, más analítica, es interesante y me gusta mucho.

PPG: A mi modo de ver, quizá la antropóloga Johanne Rappaport, haya hecho algo análogo a lo que usted ha hecho con los movimientos indígenas, en especial con el CRIC. Ella dice vamos a hacer etnografía, pero con base en proyectos. Cada uno de los participantes del grupo tiene su propio proyecto y desde ahí empiezan a interrogarse por una metodología en la que la etnografía 
ocurre precisamente en el campo mismo del diálogo y no en el escritorio de un académico que analiza su trabajo de campo. Para ese grupo, la pregunta qué es hacer etnografía se responde planteando una metodología. En ese sentido la relación con su proyecto, pues como quedó claro al comienzo, lo que usted y Jorge Silva se proponen es hacer una metodología, un modo particular de hacer documental en las condiciones de América Latina. Diría que se trata de una metodología de investigación, que tiene un carácter epistemológico a través de la cual se produce un conocimiento audiovisual, como resultado de la investigación y de los diálogos con los participantes en la realización del trabajo de cine documental. Es decir, en sus películas no se trata de la narración de una historia que se encierra en sí misma, sino de algo que tiene que ver con una realidad de largo aliento. De ahí que sus documentales, especialmente los que se refieren a las luchas de indígenas y afrodescendientes, siempre remiten a la Conquista, para hacer posible una contraposición dialéctica, mostrando que todo el problema de la colonialidad viene de la Conquista.

MR: Claro, y en ese sentido el discurso de Feliciano Valencia que dice "venimos caminando desde muy lejos, la historia." Ese es un discurso hermosísimo que hace Feliciano entrando a Cali. Además, Jesús Piñacué, cuando dice, "venimos de caminar, durante siglos de la Conquista, pero nos siguen asesinando."

PPG: Y Piñacué dice que somos un pueblo que se moviliza, un pueblo para el que caminar es caminar la palabra y en ese caminar se produce el autodescubrimiento, el conocimiento de sí mismos. En ese sentido no sé si está de acuerdo con que la metodología del documental no es otra cosa que producción de conocimiento.

MR: Sí, cuando estaba estudiando antropología yo dije voy a hacer Chircales, y me dijeron eso no es serio, eso es comunicación, no les parecía serio. Mira las obras tremendamente políticas como la de Beatriz González.

PPG: Y es allí donde usted planteaba la metodología de colaboración, pero es una colaboración distinta, de sujeto a sujeto, y una que trata de no de convertir al otro en objeto.

MR: No, jamás.
PPG: Porque a veces la etnografía misma, sutilmente o incluso sin proponérselo termina convirtiendo al otro en objeto.

MR: Mira, Cuando fue la conmemoración de los 500 años y se realizó el Festival de pueblos indígenas en el Cusco, los indígenas dijeron, nosotros reclamamos los derechos de autor, no somos informantes de ningún antropólogo; los mitos son de nosotros, que no vengan antropólogos como Reitchel Dolmatoff y nos diga que somos informantes. Además, hubo una asamblea en la Universidad Nacional con antropólogos, y llegaron los indígenas publicando libros; entonces dicen los antropólogos, nos quedamos sin oficio, ¿Ahora qué hacemos? Pues trabaje con ellos, apóyenlos. Involúcrense en otro tipo de diálogo, con otra mirada. Yo siempre estuve con otra mirada académica, distinta por ejemplo a la de Dolmatoff, que era un tipo arrogante, que tenía informantes, pero nunca decía: el mamo tal me contó tal mito, no para el sólo eran informantes. Pero si usted pregunta en la Sierra Nevada qué memoria tienen de él, no lo recuerdan mucho; son gente que pasó, pero que no dejó una amistad.

PPG: Por eso creo que no a muchos les han otorgado esa distinción que le otorgaron a usted en el Cauca que consiste en llamarla o nombrarla como "mayora".

MR: Que me nombraron mayora, creo que Carlos Andrés Bedoya estaba en Toribío, cuando estrené Testigos de un etnocidio. Fue una cuestión bellísima ser considerada como parte de los sabedores de la comunidad. Cuando me llaman, me dicen hola mayora y yo digo: tan bonito.

PPG: Teniendo en cuenta que dentro de la concepción indígena y afrodescendiente, ellos tienen muy claro lo que significa hablar "casa adentro y "casa-afuera", podríamos decir que usted ya está casa-adentro.

MR: Es que yo llevo allá como 40 años, imagínese, los he acompañado desde que nació el CRIC, y todavía estoy con ellos. Además, el haber hecho el documental de la niña Vanessa les ha llegado muy al alma a ellos, porque lo de Abel que es un personaje muy conocido por todo el valor que tiene. La historia de Maryi Vanessa es muy simbólica, ella no es cualquier niña, aquí hicimos en la Fundación la memoria, la de ella, entonces ha sido muy importante. 

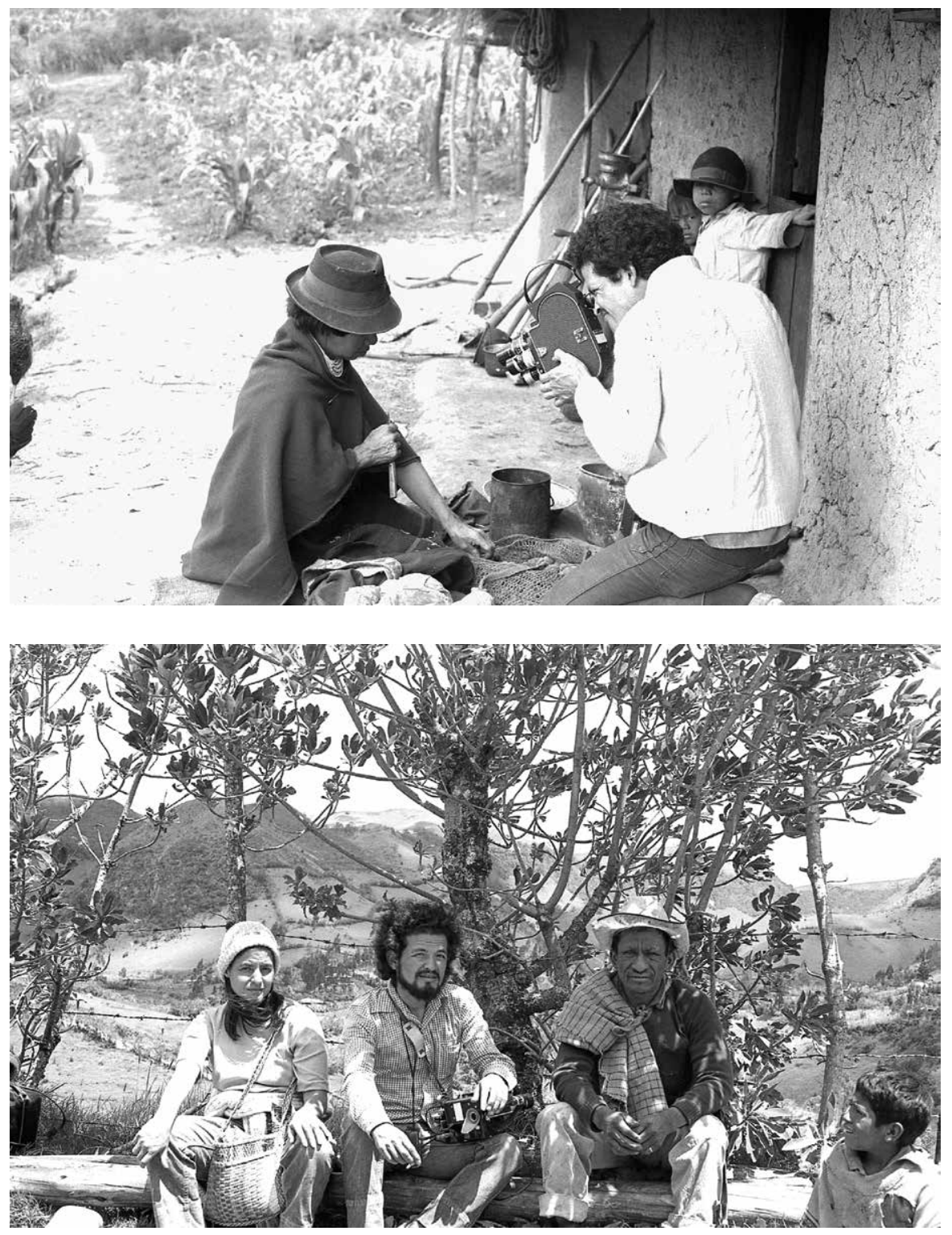

Arriba: Jorge Silva en el rodaje de Campesinos (1970-1975).

Abajo: Marta Rodríguez y Jorge Silva en el rodaje de Campesinos (1970-1975). 
PPG: Además que usted siempre le ha devuelto, por así decirlo, las películas a la comunidad como herramienta para sus luchas.

MR: Aquí hubo un movimiento de trabajadores de la cultura, cuando el Movimiento Agrario vinieron muchos artistas a acompañar el Movimiento, estaba la revista Alternativa, yo me acuerdo que estaban una serie de artistas unos del Movimiento Independiente Revolucionario, MOIR, entre ellos Clemencia Lucena. Y hacían un arte que era, como del estilo del socialismo y toda esa vaina. Había un par de artistas que hacían los grandes carteles de la Asociación Nacional de Usuarios Campesinos ANUC; $y$ hubo iun acompañamiento al Movimiento que se llamó Trabajadores de la cultura, en los 70. Y claro, nosotros siempre dábamos copias de las películas para la educación popular. Era cine, y se daba una caja así grande con la película que tenía 1200 pies como el caso de Nuestra voz de tierra memoria y futuro; aunque al poco tiempo se la quitaron los militares y los metieron presos. Allá en el Cauca tenían proyector y la usaron muchísimo. $Y$ ahora que cumplieron los cuarenta años, allá en la Hacienda la María, en Piendamó Cauca, proyectaron la película, y vinieron todos los ancianos, los que lucharon por la tierra y todo. Ellos valoran muchísimo Nuestra voz de tierra memoria y futuro.

PPG: Porque para ellos esta película es como uno de los íconos de sus luchas pasadas que les permite iluminar las luchas del presente y proyectar las luchas venideras.

MR: Si, y me invitaron a un taller allá en Popayán y los jovencitos me preguntaban, cuéntenos cómo eran los viejos que recuperaban la tierra. Claro, porque para ellos esa memoria es vital.

\section{Referencias}

Bedoya, O., Carlos, Andrés. (2011). Marta Rodríguez: memoria y resistencia. Nomadas, 35, 200-212.

Cadavid, A. (2014). Los papeles tras la cámara. Bogotá: Ministerio de Cultura.

Gómez, P. (2011). Bioestética: estética de la naturaleza o naturaleza de la estética. Calle 14 revista de investigación en el campo del arte, 5(6), 32-44. doi:https://doi.org/10.14483/udistrital.jour. c14.2011.1.a03

Gómez, P. P. (2015). Estéticas fronterizas: diferencia colonial y opción estética decolonial. Bogotá: UABS / Universidad Distrital.

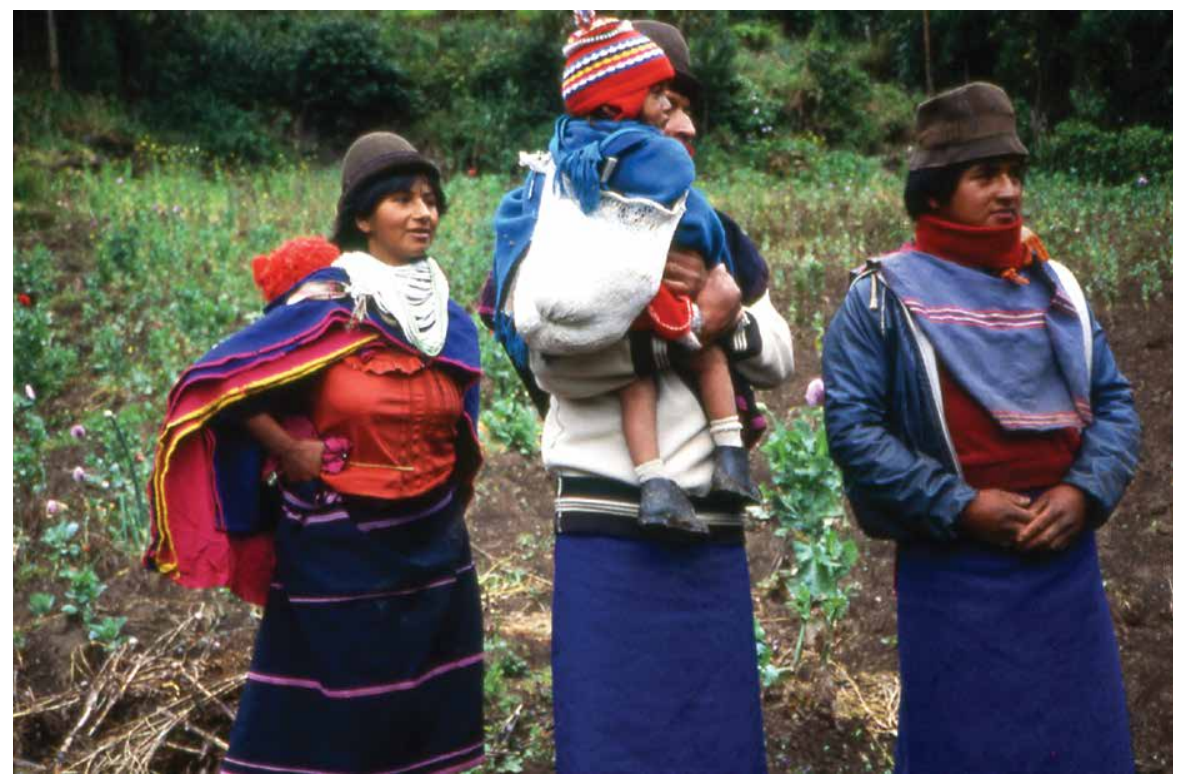

Amapola: la flor maldita (1994-1998). 

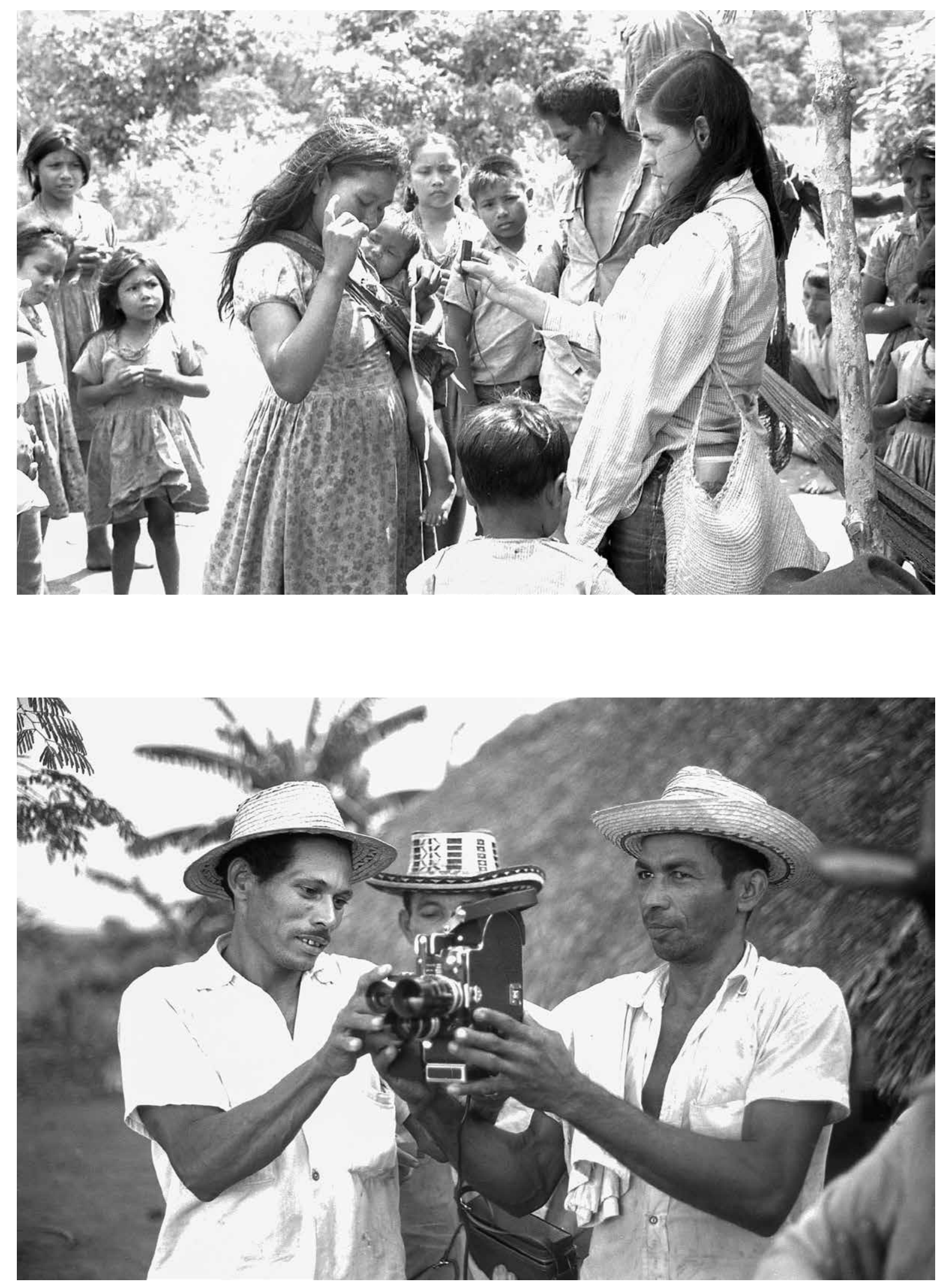

Arriba: En el rodaje de Planas (1971) Marta Rodríguez a la derecha. Abajo: Campesinos (1970-1975). 